\title{
ASSESSMENT OF ACUTE AND SUBACUTE ORAL TOXICITY ELICITED BY ETHANOLIC EXTRACT OF TURNERA APHRODISIACA LEAVES IN ALBINO RATS
}

\author{
NAVEEN KUMAR BATHULA ${ }^{1 *}$, BHIMALENDU CHOWDHURY²
}

${ }^{1}$ Department of Pharmacology and Toxicology, Pratishta Institute of Pharmaceutical Sciences, Suryapet, Hyderabad, India. ${ }^{2}$ Roland Institute of Pharmaceutical Sciences, Berhampur, Odisha, India. Email: naveen.bathula1990@gmail.com

Received: 11 March 2020, Revised and Accepted: 12 May 2020

\section{ABSTRACT}

Objectives: The medications of plant-based, herb-mineral, and animal sources have been used by the conventional medics to maintain well-being and care for diseases ever since ancient times. The current study aimed to evaluate the acute and subacute toxicities of the ethanolic extract of Turnera aphrodisiaca (TA) leaves in albino rats.

Methods: The acute toxicity studies were carried out where the maximum dosage of $5000 \mathrm{mg} / \mathrm{kg}$ body mass was used. The outcome reported for $24 \mathrm{~h}$ and singly daily for 2 weeks. The rats were weighed and a range of interpretations, for example, behavior, lesions, mortality, or any indication of sickness, was carried out daily once throughout the study. For the subacute study, four groups of ten animals (female rats) received $10 \%$ Tween 20 in distilled $\mathrm{H}_{2} \mathrm{O}$ (as control), and 250,500, and $1000 \mathrm{mg} / \mathrm{kg}$ of newly developed extracts, correspondingly, every $24^{\text {th }} \mathrm{h}$ orally for about 4 weeks. At the ending of every study, hematological study and biochemical parameters were assessed.

Results: No major variations ( $\mathrm{p}>0.05$ ) were experienced in the comparative organs, body mass, hematological, biochemical parameters, and offensive malfunctions, in comparison to control, with no mortality reported. Hence, the results of the study may direct the outcome that the intermediateperiod oral administration of the TA leaves for 4 weeks does not produce toxicity.

Conclusion: Due to these results, we may well wrap up that leaves of TA extract are non-toxic in all doses considered in this study and did not created any obvious signs in the acute and subacute oral toxicity studies.

Keywords: Acute toxicity, Biochemical investigation, Turnera aphrodisiaca, subacute toxicity.

(C) 2020 The Authors. Published by Innovare Academic Sciences Pvt Ltd. This is an open access article under the CC BY license (http://creativecommons. org/licenses/by/4. 0/) DOI: http://dx.doi.org/10.22159/ajpcr.2020.v13i7.37409

\section{INTRODUCTION}

Medicinal plants have been used in all civilizations and cultures; consequently, they have all the time performed an essential purpose globally in health-care systems. In mainly emergent nations, the native procedures of herbal management are components of the traditions and the principal method of remedial treatment. This remediation's, with a significant scope of efficacy, are collectively established, cheaply feasible and, typically, are the simply accessible foundation [1]. Medicinal plants utilized in customary medications, thus, encompass a significant task in the safeguarding of well-being globally. Due to the undesirable effects, and as well the improvement of confrontation alongside with synthesized medicines, the role of drugs obtained from medicinal plants are fetching admired in emerging nations [2]. Although, the newest studies encompass several remedial plants that had shown undesirable side-effects [3].

Turnera aphrodisiaca (TA) is usually identified as damiana. Leaves of T. aphrodisiaca have been used customarily as a tonic, diuretic, laxative, aphrodisiac, kidney impairment, menstrual, and maternity conditions $[4,5]$. According to the British herbal pharmacopeia [6] list particular signs for damiana that is associated with impotency due to anxiety neurosis, it includes new signs, for example, atonic constipation, nervous dyspepsia, depression, and coital insufficiency.

Phytochemical information on T. aphrodisiaca specifies that plant comprises cyanoglycoside [6], gonzalitosin I (flavonoid) [7], arbutin [8], damianin [9], and hexacosanol [10]; a volatile oil including $\alpha$-pinene, $\beta$-pinene, $p$-cymene, and 1,8-cineole [11] and $\beta$-sitosterol (phytosterol) [12].

Although, no study has been explained in the earlier studies on the toxic effect of T. aphrodisiaca plants. As a result, in the current study, we designed to examine the toxic effect (both oral acute and sub-acute) of $T$. aphrodisiaca leaves with a view to boost the self-assurance in safeguarding humans and to treat a range of disorders.

\section{METHODS}

Collection and identification of plant material

Leaves of TA were procured from the nearby Suryapet in September 2017. The plant was being recognized and validated by Dr. Ashok Kumar, Taxonomist, Pratishta Institute of Pharmaceutical Sciences, Suryapet, India, and the receipt sample was stored (03/TA/BOT) for further records.

\section{Preparation of sample}

The leaves of TA were collected in fresh form and were dried for 3 weeks. It was augmented into a crude powder using mortar and pestle, which was additionally treated with an electric blender to prepare a fine powder.

\section{Sample extraction}

Two hundred grams of finely powdered leaves of TA sample were constantly extracted with $0.5 \mathrm{~L}$ of $90 \% \mathrm{C}_{2} \mathrm{H}_{5} \mathrm{OH}$ [11] for about $48 \mathrm{~h}$ using a Soxhlet apparatus by keeping a temperature of $55^{\circ} \mathrm{C}$. The extracted sample was then vaporized under decreased pressure by utilizing a rotational evaporator (Modern Scientific Industries) and moreover compacted in an $\mathrm{H}_{2} \mathrm{O}$ bath at $55^{\circ} \mathrm{C}$ yield obtained was air-dried.

\section{Experimental animals}

Both sexes albino rats (Rattus norvegicus) weighed 140-155 gwere utilized for the acute and subacute toxicity studies. Both rats were acquired from animal house, NIN, Hyderabad, India. The rats were adapted to laboratory conditions for 7 days earlier to the experiments. Rats were kept at a room temp., with a $12 \mathrm{~h}$ bright/shady cycle and a humidity (55 \pm 5$) \%$. Through 
acclimatization, the animals were randomized into a test and control groups were contained independently in sterile polypropylene cages with sterilized paddy husk as a comforter. The rats were fed free entrée to a normal pellet diet and $\mathrm{H}_{2} \mathrm{O}$ impromptu. All investigational events were in observance with the Animal Ethical Committee (CPCSEA) and were permitted by the Institutional Ethical Committee.

\section{Acute oral toxicity study}

Acute oral toxicity studies were carried out in accordance with guidelines 420 for testing of chemicals of the Organization of Economic Co-operation and Development (OECD) [12]. Both the sexes (earlier fasted for $16 \mathrm{~h}$ ) rats of 7-8 weeks old were used. Ethanolic extract of TA (EETA) was dissolved in Tween $20(10 \%)$ and delivered orally at a sole dose of $5000 \mathrm{mg} / \mathrm{kg}$ at a rate of $15 \mathrm{~mL} / \mathrm{kg}$ to sexes of both rats ( $\mathrm{n}=12 ; 6$ males, 6 females), while the control group received only $10 \%$ of Tween 20 as a medium. All animals were after that permitted free admission to food and water and were witnessed for $24 \mathrm{~h}$, with exceptional care given to the first $6 \mathrm{~h}$ and 1 time each day for 2 weeks for any indications of the acute toxicity. The visible interpretation of lethality, a range of changes in physical manifestation, behavior (salivation and tiredness), and any damage or sickness were conducted 1 time every day for 2 weeks. After 2 weeks, all rats were anesthetized by i.p ketamine injection. Using tubes and non-heparinized tubes, blood samples were collected by cardiac pierce into ethylenediaminetetraacetic acid (EDTA) for hematological and biochemical investigation, respectively. Hematological and biochemical analyses were carried out at Sri Surya Diagnostic Centre, Suryapet, Telangana, India. The rats after that were euthanized by i.p ketamine injection. The organs, specifically the lung, heart, spleen, liver, and kidney, were vigilantly removed and weighed. The comparative organ weight of every rat was estimated as follows:

$$
\begin{aligned}
& \text { Comparative organ weight }= \frac{\text { Organ weight }(\mathrm{g})}{\text { Body weight of the animal }} \\
& \text { on sacrifice day }(\mathrm{g})
\end{aligned}
$$

\section{Subacute toxicity studies}

Subacute oral toxicity study was performed out in accordance with guideline 407 for testing of chemicals of OECD [12] and WHO guidelines [13], 10 female rats were used as a test. According to results of acute toxicity studies stated that EETA was non-toxic at a dose intensity of $5000 \mathrm{mg} / \mathrm{kg}$, subacute toxicity studies of EETA at the doses of 250, 500, and $1000 \mathrm{mg} / \mathrm{kg}$ body mass were delivered orally to four groups at each $24^{\text {th }} \mathrm{h}$ for 4 weeks and controls received the Tween $20(10 \%)$ as a medium with similar volume. A range of toxic indications and examination, for example, body-weight, mortality, and food and $\mathrm{H}_{2} \mathrm{O}$ intake, was supervised.

After 4 weeks, all survived rats were fasted nightly and anesthetized. For determining hematological parameters, the heparinized blood samples were assembled and the serum from non-heparinized blood was collected for identification of blood biochemistry. After the collection of blood and internal organs were detached and weighed, the rats were euthanized to conclude the comparative organ weights and noticed for some rough injuries.

\section{Weekly body-weight}

The body mass of all rats was vigilantly supervised before the beginning of the study, once weekly throughout the study and on day of the scarification.

\section{Mortality and toxic indications}

The visible interpretation of lethality, diverse changes in physical manifestations, behavior (sleepy, salivation, and tiredness), and damage or sickness were carried 1 time for 4 weeks, particularly the following dosing and up to after $4 \mathrm{~h}$ dosing [14].

\section{Comparative organ weight}

After 4 weeks, all the rats were anesthetized by an i.p ketamine injection. Using tubes and non-heparinized tubes, blood samples were assembled by cardiac pierce into EDTA for hematological and biochemical investigation, respectively. The rats after that were euthanized and the inner organs (lungs, heart, spleen, liver, and kidney) were detached and weighed to compute the comparative organ weights (by the above formula) and noticed for any sickening injuries.

\section{Hematological parameters}

Following the collection of blood from cardiac pierce into comprising EDTA tubes, different parameters were assessed at Sri Surya Diagnostic Centre, Suryapet, Telangana, India. The hematological parameters such as hemoglobin, red blood cells (RBCs), white blood cells (WBCs), differential WBCs, packed cell volume, mean corpuscular volume, mean corpuscular hemoglobin, mean corpuscular hemoglobin concentration, platelet count, red blood cell distribution width (RDW), platelet distribution width (PDW), platelet large cell ratio, mean platelet volume, and procalcitonin were assessed [15].

Table 1: The comparative organ mass of rats treated with a solo dose of EETA for 2 weeks

\begin{tabular}{lll}
\hline Organs & Control & EETA $(\mathbf{5 0 0 0} \mathbf{~ m g} / \mathbf{k g})$ \\
\hline Heart & $0.45 \pm 0.03$ & $0.42 \pm 0.01^{\text {ns }}$ \\
Liver & $3.22 \pm 0.12$ & $3.25 \pm 0.10^{\text {ns }}$ \\
Spleen & $0.31 \pm 0.03$ & $0.31 \pm 0.01^{\text {ns }}$ \\
Kidney & $0.85 \pm 0.01$ & $0.87 \pm 0.02^{\text {ns }}$ \\
Lungs & $0.81 \pm 0.04$ & $0.75 \pm 0.01^{\text {ns }}$ \\
\hline
\end{tabular}

Values are expressed as mean $\pm S D(n=6) . p>0.05^{\text {ns. }}$. EETA: Ethanolic extract of Turnera aphrodisiaca

Table 2: Outcome of EETA on hematological parameters in the acute oral toxicity studies

\begin{tabular}{llll}
\hline Parameter & Unit & Control & EETA (5000 $\mathbf{~ g / k g ) ~}$ \\
\hline $\mathrm{Hb}$ & $\mathrm{g} / \mathrm{L}$ & $139.21 \pm 2.01$ & $140.47 \pm 3.05^{\mathrm{ns}}$ \\
$\mathrm{RBC}$ 's & $10^{12} / \mathrm{L}$ & $6.42 \pm 0.32$ & $6.32 \pm 0.32^{\mathrm{ns}}$ \\
$\mathrm{PCV}$ & $\mathrm{L} / \mathrm{L}$ & $0.36 \pm 0.02$ & $0.45 \pm 0.01^{\mathrm{ns}}$ \\
$\mathrm{MCV}$ & $\mathrm{fL}$ & $53.1 \pm 0.01$ & $55.22 \pm 0.76^{\mathrm{ns}}$ \\
$\mathrm{MCH}$ & $\mathrm{Pg}$ & $19.45 \pm 0.62$ & $18.02 \pm 0.41^{\mathrm{ns}}$ \\
$\mathrm{MCHC}$ & $\mathrm{g} / \mathrm{L}$ & $332 \pm 4.32$ & $327.02 \pm 4.12^{\mathrm{ns}}$ \\
WBC's & $10^{9} / \mathrm{L}$ & $6.51 \pm 0.21$ & $9.11 \pm 0.9^{\mathrm{ns}}$ \\
Neutrophils & $\%$ & $12.31 \pm 1.01$ & $12.11 \pm 1.12^{\mathrm{ns}}$ \\
Lymphocytes & $\%$ & $85.21 \pm 1.72$ & $82.22 \pm 2.17^{\mathrm{ns}}$ \\
Monocytes & $\%$ & $3.28 \pm 0.01$ & $3.21 \pm 0.71^{\mathrm{ns}}$ \\
Eosinophils & $\%$ & $1.02 \pm 0.02$ & $1.29 \pm 0.12^{\mathrm{ns}}$ \\
Platelet count & $10^{9} / \mathrm{L}$ & $875 \pm 10.36$ & $856.00 \pm 16.31^{\mathrm{ns}}$ \\
\hline
\end{tabular}

Values are expressed as mean $\pm S D(n=6) . p>0.05^{\text {ns }}$. EETA: Ethanolic extract of Turnera aphrodisiaca, Hb: Hemoglobin, RBCs: Red blood cells, WBCs: White blood cells, PCV: Packed cell volume, MCV: Mean corpuscular volume, MCH: Mean corpuscular hemoglobin, MCHC: Mean corpuscular hemoglobin concentration

Table 3: Outcome of EETA on biochemical parameters in acute oral-toxicity studies

\begin{tabular}{llll}
\hline Parameter & Unit & Control & EETA (5000 mg/kg) \\
\hline $\mathrm{Na}^{+}$ & $\mathrm{mmol} / \mathrm{L}$ & $139.0 \pm 0.22$ & $132.22 \pm 0.07^{\mathrm{ns}}$ \\
$\mathrm{K}^{+}$ & $\mathrm{mmol} / \mathrm{L}$ & $6.95 \pm 0.12$ & $7.22 \pm 0.31^{\mathrm{ns}}$ \\
$\mathrm{Cl}^{-}$ & $\mathrm{mmol} / \mathrm{L}$ & $114.0 \pm 0.72$ & $106.31 \pm 0.02^{\mathrm{ns}}$ \\
Urea & $\mathrm{mmol} / \mathrm{L}$ & $7.20 \pm 0.43$ & $7.35 \pm 0.21^{\mathrm{ns}}$ \\
Creatinine & $\mu \mathrm{mol} / \mathrm{L}$ & $42.17 \pm 0.43$ & $45.11 \pm 0.41^{\mathrm{ns}}$ \\
Uric acid & $\mathrm{mmol} / \mathrm{L}$ & $0.21 \pm 0.13$ & $0.18 \pm 0.02^{\mathrm{ns}}$ \\
Total protein & $\mathrm{g} / \mathrm{L}$ & $67.73 \pm 0.22$ & $69.50 \pm 0.34^{\mathrm{ns}}$ \\
Albumin & $\mathrm{g} / \mathrm{L}$ & $34.33 \pm 0.56$ & $37.10 \pm 0.74^{\mathrm{ns}}$ \\
Globulin & $\mathrm{g} / \mathrm{L}$ & $29.94 \pm 0.42$ & $31.44 \pm 0.55^{\mathrm{ns}}$ \\
Albumin/globulin & & $2.09 \pm 0.10$ & $1.08 \pm 0.07^{\mathrm{ns}}$ \\
ratio & & & \\
ALP & $\mathrm{U} / \mathrm{L}$ & $137 \pm 7.31$ & $134.24 \pm 9.71^{\mathrm{ns}}$ \\
AST & $\mathrm{U} / \mathrm{L}$ & $75.11 \pm 3.2$ & $172.13 \pm 2.33^{\mathrm{ns}}$ \\
ALT & $\mathrm{U} / \mathrm{L}$ & $44.11 \pm 0.73$ & $46.61 \pm 0.54^{\mathrm{ns}}$ \\
\hline
\end{tabular}

Values are expressed as mean \pm SD $(n=6) . p>0.05^{\text {ns }}$. EETA: Ethanolic extract of Turnera aphrodisiaca, ALT: Alanine aminotransferase, ALP: Alkaline phosphatase, AST: Aspartate aminotransferase 
Table 4: The outcome of EETA leaves on body mass of rats (g) at several days

\begin{tabular}{|c|c|c|c|c|c|}
\hline \multirow[t]{2}{*}{ Group } & \multirow[t]{2}{*}{ Doses } & \multicolumn{4}{|l|}{ Weight } \\
\hline & & $1^{\text {st }}$ week & $2^{\text {nd }}$ week & $3^{\text {rd }}$ week & $4^{\text {th }}$ week \\
\hline Control & - & $133.11 \pm 3.01$ & $137.14 \pm 6.14$ & $143.42 \pm 4.18$ & $146.23 \pm 5.87$ \\
\hline I & $250 \mathrm{mg} / \mathrm{kg}$ & $136.33 \pm 4.11$ & $143.16 \pm 4.68$ & $147.32 \pm 6.23$ & $152.55 \pm 6.72$ \\
\hline II & $500 \mathrm{mg} / \mathrm{kg}$ & $141.21 \pm 5.22$ & $142.16 \pm 5.31$ & $151.19 \pm 5.91$ & $158.85 \pm 4.82$ \\
\hline III & $1000 \mathrm{mg} / \mathrm{kg}$ & $142.24 \pm 2.21$ & $143.21 \pm 4.72$ & $151.16 \pm 4.68$ & $152.22 \pm 3.02$ \\
\hline
\end{tabular}

Values are expressed as mean \pm SD $(n=6)$. $p>0.05$. EETA: Ethanolic extract of Turnera aphrodisiaca

Table 5: The comparative organ mass of rats treated with different doses of EETA for 4 weeks

\begin{tabular}{lcccc}
\hline Organ & Control & $\begin{array}{c}\text { EETA (250 } \\
\mathbf{m g} / \mathbf{k g})\end{array}$ & $\begin{array}{c}\text { EETA (500 } \\
\mathbf{m g} / \mathbf{k g})\end{array}$ & $\begin{array}{c}\text { EETA (1000 } \\
\mathbf{m g} / \mathbf{k g})\end{array}$ \\
\hline Heart & $0.44 \pm 0.11$ & $0.42 \pm 0.03^{\text {ns }}$ & $0.41 \pm 0.03^{\text {ns }}$ & $0.42 \pm 0.03^{\text {ns }}$ \\
Liver & $3.04 \pm 0.12$ & $3.25 \pm 0.16^{\text {ns }}$ & $3.15 \pm 0.03^{\text {ns }}$ & $3.12 \pm 0.06^{\text {ns }}$ \\
Spleen & $0.31 \pm 0.03$ & $0.32 \pm 0.02^{\text {ns }}$ & $0.28 \pm 0.04^{\text {ns }}$ & $0.19 \pm 0.02^{\text {ns }}$ \\
Kidney & $0.75 \pm 0.03$ & $0.76 \pm 0.02^{\text {ns }}$ & $0.72 \pm 0.01^{\text {ns }}$ & $0.72 \pm 0.02^{\text {ns }}$ \\
Lungs & $0.86 \pm 0.05$ & $0.94 \pm 0.08^{\text {ns }}$ & $0.85 \pm 0.03^{\text {ns }}$ & $0.83 \pm 0.02^{\text {ns }}$ \\
\hline
\end{tabular}

Values are expressed as mean $\pm S D(n=10)$. $p>0.05^{\text {ns }}$. EETA: Ethanolic extract of Turnera aphrodisiaca

\section{Biochemical estimations}

Blood samples were centrifuged at $4000 \mathrm{rcf}$ for $5 \mathrm{~min}$. The serum obtained was analyzed at Sri Surya Diagnostic Centre, Suryapet, Telangana, India, for a range of parameters such as $\mathrm{Na}^{+}, \mathrm{K}^{+}, \mathrm{Cl}$, urea, uric acid, creatinine, albumin, globulin, albumin-globulin ratio, total protein, and total bilirubin [15].

\section{Statistical analysis}

All estimations were reported as the mean \pm SD and the outcome was analyzed by one-way ANOVA ensued by Tukey's multiple comparison tests using GraphPad Prism (GraphPad, CA, USA).

\section{RESULTS}

\section{Acute-oral toxicity study}

EETA at a dose of $5000 \mathrm{mg} / \mathrm{kg}$ created no toxic outcome on the behavioral rebuttals of the treated animals (solo dose) and witnessed for 2 weeks. There were no indications of modifications in the behavior forms, skin, eyes, salivation, and diarrhea of the animals. Nor lethality neither major mass loss was experienced. There were usually no noteworthy variations pragmatic in the comparative organ mass (Table 1). In the current study, it was observed that no major alteration in the hematological and biochemical requirements in the EETA treated group compared to the control group (Tables 2 and 3). Even though several variations have been observed; however, the hematological and biochemical requirements demonstrated no major alteration in the physiological conditions. The alterations emerged merely in two treated animals. The rest of the animals ( 8 rats) revealed no modifications in their histopathology. The $\mathrm{LD}_{50}$ of TA was, consequently, anticipated to be in excess of $5000 \mathrm{mg} / \mathrm{kg}$.

\section{Subacute toxicity assessment}

\section{Body weight weekly}

A week's time, body mass was established on the early day of each week of four groups. With control, $1^{\text {st }}$ one was EETA of $250 \mathrm{mg} / \mathrm{kg}$, II ${ }^{\text {nd }}$ EETA of $500 \mathrm{mg} / \mathrm{kg}$, and final as EETA of $1000 \mathrm{mg} / \mathrm{kg}$. No major alterations in the body mass were noticed (Table 4).

\section{Clinical observation and lethality}

Everyday oral management of EETA for 4 weeks did not create any sign of toxicity in animals, together with the maximum dose experienced at $1000 \mathrm{mg} / \mathrm{kg}$ body mass. No mortality or apparent clinical indications were identified in any group during the study. Not at all, the animals displayed indications of toxicities in their salivation, fur, eyes, and skin.
The treated animals were evaluated based on the intake of water and meal for the whole study with no unusual outcome as compared to control.

\section{Comparative organ weight}

Comparative organ weights of 4-week treated animals are depicted in Table 5. The comparative organ mass of every organ reported at the examination in the processed groups did not demonstrate major alterations $(p>0.05)$ as compared to control.

\section{Hematological parameters}

The outcomes of subacute management of EETA on hematological parameters are depicted in Table 6. Mainly hematological parameters, for example, hemoglobin, total RBCs, WBCs, RDW, lymphocytes, monocytes, neutrophils, and platelet count, in treated animals were not considerably unlike as of the control.

\section{Biochemical analysis}

The outcome of subacute management of EETA on biochemical parameters is depicted in Table 7. The EETA had no consequence on the serum electrolytes (e.g., sodium, chloride, etc.). Parameters, such as urea, uric acid, and creatinine, did not disclose at all major alterations. No statistically noteworthy variations in the parameters of liver function, for example, alanine aminotransferase, alkaline phosphatase, and aspartate aminotransferase were reported. Furthermore, no pertinent modifications were established in globulin, albumin, and total protein.

\section{DISCUSSION}

For hundreds of years, plant-based medicaments and their preparations have been believed designated as harmless and useful owing to their slight adverse implications. This statement might have prejudiced the haphazard exploit of these preparations to a huge scope among the rural population. The treatments are typically operated over an extended period devoid of appropriate dosage surveillance by the professionals and need of responsiveness of the toxic effects that may produce from such formulations [16-18]. Consequently, systematic awareness against oral-toxicity is greatly desirable, which will not just assist spot the doses that might be used consequently, however, as well to divulge the potential clinical alterations induced by agents in the study. Despite the pharmacological advantages of the TA, comprehensive information concerning subacute toxicities of this remedial plant is deficient. Therefore, the current study was performed to estimate and emphasize the acute and subacute toxicity of TA leaves in albino rats. Furthermore, the dosage of $5000 \mathrm{mg} / \mathrm{kg}$ of EETA leaves had no side effect on the treated animal's up to 2 weeks of surveillance. There were no major alterations in the mass and organs of the rats.

Subacute studies afford details on dosage schemas, target organ toxicity, and recognize visible side effects, which might influence the usual life duration of investigational animals. Therefore, in the present study, the leaves of TA were assessed in rats at a dose of 250, 500, and $1000 \mathrm{mg} / \mathrm{kg}$ for 4 weeks. The body mass alterations provide a responsive sign of universal healthiness of animals $[19,20]$. Following 4 weeks of management of extract, all the rats displayed a typical augmentation in body mass. It can be affirmed that the leaves of TA did not obstruct the regular metabolic activities of rats. The noteworthy 
Table 6: Outcome of EETA on hematological parameters in subacute toxicity studies

\begin{tabular}{|c|c|c|c|c|c|}
\hline Parameter & Unit & Control & $250 \mathrm{mg} / \mathrm{kg}$ & $500 \mathrm{mg} / \mathrm{kg}$ & $1000 \mathrm{mg} / \mathrm{kg}$ \\
\hline $\mathrm{Hb}$ & $\mathrm{g} / \mathrm{L}$ & $151.23 \pm 0.72$ & $145.10 \pm 0.12$ & $145.32 \pm 0.72$ & $149.51 \pm 0.41$ \\
\hline RBC's & $10^{12} / \mathrm{L}$ & $7.51 \pm 0.16$ & $7.62 \pm 0.21^{\mathrm{ns}}$ & $7.21 \pm 0.36^{\mathrm{ns}}$ & $7.47 \pm 0.23^{\mathrm{ns}}$ \\
\hline PCV & $\mathrm{L} / \mathrm{L}$ & $0.47 \pm 0.12$ & $0.42 \pm 0.08^{\mathrm{ns}}$ & $0.42 \pm 0.32^{\mathrm{ns}}$ & $0.41 \pm 0.11^{\mathrm{ns}}$ \\
\hline MCV & $\mathrm{fL}$ & $55.11 \pm 0.73$ & $54.31 \pm 0.22^{\mathrm{ns}}$ & $54.82 \pm 0.22^{\mathrm{ns}}$ & $54.11 \pm 0.13^{\mathrm{ns}}$ \\
\hline $\mathrm{MCH}$ & pg & $18.17 \pm 0.18$ & $17.14 \pm 0.21^{\mathrm{ns}}$ & $17.42 \pm 0.33^{\mathrm{ns}}$ & $17.77 \pm 0.44^{\mathrm{ns}}$ \\
\hline $\mathrm{MCHC}$ & $\mathrm{g} / \mathrm{L}$ & $311.12 \pm 0.12$ & $312.04 \pm 0.15^{\mathrm{ns}}$ & $317.31 \pm 0.33^{\text {ns }}$ & $310.72 \pm 0.34^{\mathrm{ns}}$ \\
\hline WBC's & $10^{9} / \mathrm{L}$ & $8.22 \pm 0.14$ & $8.22 \pm 0.21^{\mathrm{ns}}$ & $8.43 \pm 0.29^{\mathrm{ns}}$ & $7.63 \pm 0.28^{\mathrm{ns}}$ \\
\hline Lymphocytes & $\%$ & $86.12 \pm 2.91$ & $83.03 \pm 2.22^{\mathrm{ns}}$ & $86.21 \pm 1.12^{\mathrm{ns}}$ & $86.32 \pm 1.01^{\mathrm{ns}}$ \\
\hline Monocytes & $\%$ & $2.12 \pm 0.03$ & $2.51 \pm 0.22^{\mathrm{ns}}$ & $2.71 \pm 0.75^{\mathrm{ns}}$ & $2.16 \pm 0.21^{\mathrm{ns}}$ \\
\hline Platelet count & $10^{9} / \mathrm{L}$ & $833.64 \pm 48.22$ & $833.31 \pm 42.32^{\mathrm{ns}}$ & $840.14 \pm 44.41^{\mathrm{ns}}$ & $840.02 \pm 52.33^{\mathrm{ns}}$ \\
\hline RDW & $\%$ & $12.31 \pm 2.11$ & $13.01 \pm 1.83^{\mathrm{ns}}$ & $13.59 \pm 1.13^{\mathrm{ns}}$ & $13.13 \pm 1.19^{\mathrm{ns}}$ \\
\hline PDW & $\mathrm{fL}$ & $12.2 \pm 0.02$ & $10.71 \pm 0.31^{\mathrm{ns}}$ & $11.59 \pm 0.03^{\mathrm{ns}}$ & $9.56 \pm 0.17^{\mathrm{ns}}$ \\
\hline P-LCR & $\%$ & $13.52 \pm 0.21$ & $15.34 \pm 0.32^{\mathrm{ns}}$ & $12.22 \pm 0.32^{\mathrm{ns}}$ & $14.72 \pm 0.21^{\mathrm{ns}}$ \\
\hline MPV & $\mathrm{fL}$ & $8.74 \pm 0.03$ & $8.54 \pm 0.07^{\mathrm{ns}}$ & $7.26 \pm 0.02^{\mathrm{ns}}$ & $7.56 \pm 0.21^{\mathrm{ns}}$ \\
\hline PCT & $\%$ & $0.91 \pm 0.32$ & $0.81 \pm 0.36^{\mathrm{ns}}$ & $0.67 \pm 0.41^{\mathrm{ns}}$ & $0.65 \pm 0.34^{\mathrm{ns}}$ \\
\hline
\end{tabular}

Values are expressed as mean \pm SD $(n=10)$. $p>0.05^{\text {ns. }}$. EETA: Ethanolic extract of Turnera aphrodisiaca, Hb: Hemoglobin, RBCs: Red blood cells, WBCs: White blood cells, PVC: Packed cell volume, MCV: Mean corpuscular volume, MCH: Mean corpuscular hemoglobin, MCHC: Mean corpuscular hemoglobin concentration, RDW: Red blood cell distribution unit, PDW: Platelet distribution width, P-LCR: Platelet large cell ratio, MPV: Mean platelet volume, PCT: Procalcitonin

Table 7: Outcome of EETA on biochemical parameters in the subacute oral toxicity studies

\begin{tabular}{|c|c|c|c|c|c|}
\hline Parameter & Unit & Control & $250 \mathrm{mg} / \mathrm{kg}$ & $500 \mathrm{mg} / \mathrm{kg}$ & $1000 \mathrm{mg} / \mathrm{kg}$ \\
\hline Sodium & $\mathrm{mmol} / \mathrm{L}$ & $136.01 \pm 0.13$ & $132.22 \pm 0.93^{\text {ns }}$ & $133.70 \pm 0.87^{\mathrm{ns}}$ & $133.20 \pm 0.57^{\mathrm{ns}}$ \\
\hline Chloride & $\mathrm{mmol} / \mathrm{L}$ & $101.23 \pm 0.12$ & $112.73 \pm 0.35^{\mathrm{ns}}$ & $101.11 \pm 0.23^{\mathrm{ns}}$ & $101.20 \pm 0.22^{\mathrm{ns}}$ \\
\hline Urea & $\mathrm{mmol} / \mathrm{L}$ & $6.62 \pm 0.24$ & $7.14 \pm 0.13^{\mathrm{ns}}$ & $6.19 \pm 0.23^{\mathrm{ns}}$ & $6.71 \pm 0.11^{\mathrm{ns}}$ \\
\hline Creatinine & $\mu \mathrm{mol} / \mathrm{L}$ & $46.32 \pm 0.43$ & $44.14 \pm 0.83^{\mathrm{ns}}$ & $42.11 \pm 0.21^{\mathrm{ns}}$ & $46.70 \pm 0.44^{\mathrm{ns}}$ \\
\hline Uric acid & $\mathrm{mmol} / \mathrm{L}$ & $0.14 \pm 0.24$ & $0.19 \pm 0.23^{\mathrm{ns}}$ & $0.13 \pm 0.29^{\mathrm{ns}}$ & $0.25 \pm 0.22^{\mathrm{ns}}$ \\
\hline Total protein & $\mathrm{g} / \mathrm{L}$ & $68.52 \pm 0.93$ & $68.33 \pm 0.73^{\mathrm{ns}}$ & $69.30 \pm 1.12^{\mathrm{ns}}$ & $68.21 \pm 0.93^{\mathrm{ns}}$ \\
\hline Albumin & $\mathrm{g} / \mathrm{L}$ & $36.27 \pm 0.23$ & $37.22 \pm 0.02^{\mathrm{ns}}$ & $38.37 \pm 0.03^{\mathrm{ns}}$ & $38.82 \pm 0.13^{\mathrm{ns}}$ \\
\hline Albumin/globulin ratio & & $1.13 \pm 0.20$ & $1.29 \pm 0.21^{\mathrm{ns}}$ & $1.38 \pm 0.03^{\mathrm{ns}}$ & $1.34 \pm 0.41^{\mathrm{ns}}$ \\
\hline ALP & $\mathrm{U} / \mathrm{L}$ & $131.82 \pm 6.27$ & $132.20 \pm 10.22^{\mathrm{ns}}$ & $134.35 \pm 12.32^{\mathrm{ns}}$ & $135.44 \pm 11.34^{\mathrm{ns}}$ \\
\hline AST & $\mathrm{U} / \mathrm{L}$ & $71.01 \pm 6.92$ & $74.10 \pm 6.12^{\mathrm{ns}}$ & $75.31 \pm 7.23^{\mathrm{ns}}$ & $77.66 \pm 6.23^{\mathrm{ns}}$ \\
\hline ALT & $\mathrm{U} / \mathrm{L}$ & $48.77 \pm 1.12$ & $44.31 \pm 2.32^{\mathrm{ns}}$ & $48.41 \pm 2.31^{\mathrm{ns}}$ & $50.88 \pm 1.33^{\text {ns }}$ \\
\hline Bilirubin (Total) & $\mathrm{mg} / \mathrm{dL}$ & $0.45 \pm 0.02$ & $0.34 \pm 0.11^{\mathrm{ns}}$ & $0.44 \pm 0.31^{\mathrm{ns}}$ & $0.54 \pm 0.12^{\mathrm{ns}}$ \\
\hline
\end{tabular}

Values are expressed as mean \pm SD $(n=6) . p>0.05^{\text {ns }}$ Not significant. EETA: Ethanolic extract of Turnera aphrodisiaca, ALT: Alanine aminotransferase, ALP: Alkaline phosphatase, AST: Aspartate aminotransferase

addition in the meal and $\mathrm{H}_{2} \mathrm{O}$ ingestion is measured as being liable for expansion and increase in body mass.

The outcome of the present study demonstrated no major modifications in the comparative organ-weight of control and test groups, which exhibited such that not any of the organs were harmfully impacted, neither shown any indications of toxicity during the investigation.

The hematological variables can be utilized to establish the blood involving the tasks of plant extract. The extort reported an insignificant distinction on the RBC index that proposed that TA does not influence the morphology, erythropoiesis, or osmotic tenderness of RBCs [21]. Assessment of serum biochemistry was performed to recognize the potential signs in renal and hepatic functions influenced by the extract. In addition, earlier, no study has been indicated on leaves (i.e., separation of chemical components and its categorization).

\section{CONCLUSION}

In view of these results, we may well wrap up that leaves of TA extract are non-toxic in all doses considered in this study and did not created any obvious signs in the acute and subacute oral toxicity studies. Moreover, the information of acute and subacute studies of toxicity on leaves of $T A$ was acquired so that to augment the assurance in its well-being to humans for the employment in the preparation of medicaments. Further studies as well require additional experimental endeavors, for example, subchronic toxicity studies, the outcome of the extract on the fetuses, and their breeding competence to inclusive protection outline of TA.

\section{ACKNOWLEDGMENT}

The authors are indebted to the Management, Principal and HOD, Pharmacology, Pratishta Institute of Pharmaceutical Sciences, Suryapet, Hyderabad, India, for offering the essential chemicals, instruments, and further laboratory amenities to perform the study.

\section{CONFLICTS OF INTEREST}

The authors declare no conflicts of interest.

\section{AUTHORS' FUNDING}

Nil.

\section{REFERENCES}

1. Patil UH, Gaikwad DK. Phytochemical profile and antibacterial activity of stem bark of Anogeissus latifolia. Pharm J 2010;2:70-3.

2. Dias FD, Takahashi CS. Cytogenetic evaluation of aqueous extracts of the medicinal plants Alpinia nutans rose (Zingiberaceae) and Pogostemon heyneanus benth (labitae) on Wistar rats and Allium cepa (Liliaceae) root tip cells. Braz J Genet 1994;17:175-80.

3. Nath P, Yadav KA. Acute and sub-acute oral toxicity assessment of the methanolic extract from leaves of Hibiscus rosa-sinensis L. in mice. J Int Ethnopharmacol 2015;4:70-3.

4. Hocking GM. A Dictionary of Terms in Pharmacognosy. $1^{\text {st }}$ ed. Illinois: Charles C. Thomas; 1955.

5. Parfitt K. Martindale, the Complete Drug Reference. $32^{\text {nd }}$ ed. London: Pharmaceutical Press; 1999.

6. Pocket WB. Manual of Homoeopathic Materia Medica. $9^{\text {th }}$ ed. New 
Delhi: Jain Publisher Private Limited; 1988.

7. Spencer KC. Tetraphyllin B from Turnera diffusa. Planta Med 1981;43:175-78.

8. Dominguez XA. Isolation of 5-hydroxy-7, 3', 4'-trimethoxy $\beta$ avone from Turnera diffusa. Planta Med 1976;30:68-71.

9. Auterhoff H, Hackle HP. Components of damiana drug. Arch Pharm 1968;301:537-44.

10. Steinmetz EF. Damianae folia. Acta Phyther 1960;7:1-2.

11. Organization for Economic Co-operation and Development. Guidance Document on Acute Oral Toxicity Testing 420. Paris, France: Organization for Economic Co-operation and Development; 2008.

12. Organization for Economic Co-operation and Development. Guidance Document on Subacute Oral Toxicity Testing 407. Paris, France: Organization for Economic Co-operation and Development; 2008.

13. World Health Organization. General Guidelines for Methodologies on Research and Evaluation of Traditional Medicine. Geneva, Switzerland: World Health Organization; 2000. p. 35.

14. Das N, Goshwami D, Hasan M, Sharif R, Zahir S. Evaluation of acute and subacute toxicity induced by methanol extract of Terminalia citrina leaves in Sprague Dawley rats. J Acute Dis 2015;4:316-21.
15. Yuet PK, Darah I, Chen Y, Sreeramanan S, Sasidharan S. Acute and subchronic toxicity study of Euphorbia hirta L. methanol extract in rats. Biomed Res Int 2013;182064-71.

16. Bigoniya P, Sahu T, Tiwari V. Hematological and biochemical effects of sub-chronic artesunate exposure in rats. Toxicol Rep 2015;2:280-8.

17. Wani SUD, Gangadharappa HV, Ashish NP. Formulation, development and characterization of drug delivery systems based telmisartan encapsulated in silk fibroin nanosphere's. Int J Appl Pharm 2019;11:247-54

18. Kakkar V, Wani SUD, Gautam SP, Qadrie ZL. Role of microspheres in novel drug delivery systems: Preparation methods and applications. Int J Curr Pharm Res 2020;12:1-6.

19. National Research Council. Toxicity Testing for Assessing Environmental Agents Interim Report. Washington, DC, USA: National Academics Press; 2006.

20. Kluwe WM. Renal functions tests as indicators of kidney injury in subacute toxicity studies. Toxicol Appl Pharmacol 1981;57:414-24.

21. Olorunnisola OS, Bradley G, Afolayan AJ. Acute and subchronic toxicity studies of methanolic extract of Tulbaghia violacea rhizomes in Wistar rats. Afr J Biotechnol 2012;11:14934-40. 